\title{
CHARACTERISTICS OF THE DESIGN OF THE EDUCATIONAL PROCESS IN THE PREPARATION OF COMPETITIVE PERSONNEL Opaeva G.A. Email: Opaeva656@scientifictext.ru
}

\author{
Opaeva Gulbahar Aymanovna - Assistant, Teacher of mathematics, \\ DEPARTMENT OF FUNCTIONAL ANALYSIS, ALGEBRA AND GEOMETRY, \\ KARAKALPAK STATE UNIVERSITY, NUKUS, REPUBLIC OF UZBEKISTAN
}

\begin{abstract}
: the article deals with the use of innovative pedagogical technologies and the fundamentals of training for the training of modern staff. The article is intended for working in all segments of the education system, teachers, researchers and specialists in the field of science, education and vocational training, for use in the development and improvement of methodological developments. Designing an educational process is an effective way of organizing and developing an educational practice. Education is also rapidly developing in the field of education. Planning and design of the educational process and the organization of the educational process on this basis will enhance the effectiveness and quality of education.
\end{abstract}

Keywords: modern educational technologies, design of education, teaching materials.

\section{ХАРАКТЕРИСТИКА ПРОЕКТИРОВАНИЯ УЧЕБНОГО ПРОЦЕССА ПРИ ПОДГОТОВКЕ КОНКУРЕНТОСПОСОБНЫХ КАДРОВ Опаева Г.А.}

\author{
Опаева Гулбахар Аймановна - ассистент, преподаватель по математике, \\ кафедра функиионального анализа, алгебры и геометрии, \\ Каракалпакский государственный университет, г. Нукус, Республика Узбекистан
}

\begin{abstract}
Аннотация: в статье рассматриваются вопросы использования инновационньх педагогических технологий и основы подготовки кадров для подготовки современных кадров. Статья предназначена для работы во всех сегментах системы образования, учителей, научных работников и спеииалистов в области науки, образования $u$ профессиональной подготовки, для использования при разработке и совершенствовании методических разработок. Проектирование учебного прочесса - эффективный способ организации и развития учебной практики. Образование также быстро развивается в сфере образования. Планирование и проектирование учебного процесса и организаџия учебного прочесса на этой основе позволят повысить эффективность и качество образования.
\end{abstract}

Ключевые слова: современные образовательные технологии, дизайн образования, учебные материаль.

New and higher requirements are being drawn to the specialists trained in the current educational system of Uzbekistan. The market economy has its own rules and requirements. One of them is to train competitive specialists.

Modern expert staff's ability to think should be analytic mind, inductive and deductive, intelligent thinking, analysis and synthesis, algorithmic thinking, generalization and predictability. Their attention should be steadfast, exemplary, inclusive, broad and profound, and are determined by the fact that they can be viewed by far-sighted people in the interests of the majority, with the faster, stronger sense of responsibility than others.

The formation of the above characters and their regular development are carried out directly in the process of analysis of each science and technological process.

It is known that any pedagogical technology is based on the principles of the new educational curriculum, and should be addressed to the student himself $[1,3]$.

It is desirable to introduce modern educational technologies into the education system in the training of competitive personnel, as a result of which the following can be achieved:

- the skilled cadres successfully master theoretical and practical knowledge in their field of professionalism and skill;

- the professional staff will have the qualities of a person of general and professional culture and of social significance that guarantees successful life in society;

- expert cadres independently make critical conclusions and anticipate emerging challenges and seek the best ways to use them with cutting-edge technologies and solve them by technology.

At present, the term "teaching technology" is used in two ways:

Given the sharp increase in information in our daily lives and the inability to reach an age-skilled specialist, achieving a predetermined result is based on guaranteed pedagogical technology [2,5].

In the current third stage of implementation of the National Program for Personnel Training, it is required to introduce effective forms and methods of organization and implementation of the educational process to achieve high quality indicators $[3,7]$.

The organization of education based on pedagogical technologies includes:

1. Preparation of educational project.

The training project is drawn up by an educator or an expert member and it is done in the following order: 
- analyze the content of the projected subject to the requirements of the state educational standards and allocate time for its implementation;

- formation of knowledge and skills;

- analysis of educational materials;

- training materials are divided into sections and the individual goals and results are formed for each section;

- methods and teaching aids that ensure the achievement of targeted goals and expected results at the designated time;

- develop pedagogical monitoring of project implementation information and management system;

- technological map for every course in the project.

Creating a new generation of textbooks, based on designing teaching materials in Higher Mathematics, will serve as a basis for improving the quality of education. On the basis of the research on the creation of new generation of educational literature in higher mathematics, the following conclusions were drawn. Specifically:

-analyze the mathematical education reform, the textbooks and manuals created in the new generation of mathematical syllabuses;

-studying the content, method, form, tool and learning processes of the advanced countries education system.

Conducting research to apply their experiences in education;

-solving problems related to the creation of a new generation of mathematics teaching literature in the education system, ensuring the continuity and continuity of the content of education;

-upgrading the methodological skills of professors and teachers who create new generation educational literature to modern requirements;

-preparing a new generation of educational literature aimed at bringing the student knowledge to the requirements of the curriculum, using independent work;

-creating a new generation of teaching literature that encourages students to pursue collaborative learning, based on new information and pedagogical technology curricula in education $[4,56]$.

2. Implementation of educational project.

The process of implementing an educational project includes:

- the student is advised and explained the goals of the educational process;

- used methods, means, forms are used in educational process;

- educators' activities are encouraged by any means;

- the quality of the educational process is constantly monitored and analyzed.

It guarantees the development of qualified personnel who will be trained in the process of training, retraining and raising the qualifications of the specialist, organizing the educational process on the basis of this process, the role of the labor market, and the proper functioning of the economic mechanism in the society.

Improving the quality and effectiveness of education and the issues of training competitive personnel are realized on the basis of the creation of projects for the activities of the teacher, as well as the creation of modern and interactive methods for use in practice.

The design of the educational process is widely used in modern education, and also recently has been scrutinized in both theoretical and practical methodology and didactics. Designing the educational process is one of the main forms of supporting modern educational technologies in the educational process.

\section{References / Список литературы}

1. Tajiev M., Alimov A.Y. and others. Pedagogical technology - introduction to educational process. // "Tafakkur", Tashkent-2010.

2. Rahimov O.D. Innovative pedagogical technologies. Karshi, 2011.

3. Bozorova S. Technology of Vocational Education in Higher Education. T.: "Science and Technology", 2006. 145 $\mathrm{p}$.

4. Azizhodjaeva N.N. Pedagogical technology and pedagogical skills. T .: TDPU, 2003.

5. Opaeva G.A. Methodological aspects of teaching mathematics with the use of computer mathematical systems.// VI International Correspondence Scientific Specialized Conference «International scientific review of the problems of philisophy, psychology and pedagogy» // Boston.USA.October 10-11, 2018. P. 112-114. [Electronic resource]. URL: https: scientific-conference.com/ (дата обращения: 01.02.2019). 